
Selama ini, penelitian mengenai kepemimpinan transformasional hanya memusatkan perhatian pada faktor-faktor penyebab dan pengaruhnya pada suatu perilaku (Yukl, 213), khususnya pengaruhnya terhadap hasil-hasil organisasi. Penelitian-penelitian selama ini yang dilakukan masih kurang bahkan jarang yang membahas mengenai proses kepemimpinan transformasional yang berdampak pada hasil-hasil yang dicapai oleh organisasi (Northouse, 2016). Hal tersebut dipertegas, ketika para peneliti tertarik dalam membahas mengenai proses pengaruh kepemimpinan transformasional dalam mencapai hasil-hasil yang diharapkan oleh organisasi yang sebenarnya penelitian-penelitian mengenai hal tersebut memang masih jarang dilakukan.

Bass (1995) menyatakan bahwa kepemimpinan transformasional, sebagaimana bentuk perilaku kepemimpinan yang sering diadopsi, secara tradisional dipandang sebagai variabel bebas yang memiliki konsekuensi-konsekuensi dalam kaitannya dengan perilaku kewargaan organisasi. Cascio (1993) dan Katzenbach et al (1995) menyatakan bahwa seiring meningkatnya perhatian terhadap keberhasilan perubahan dalam manajemen organisasi, kepemimpinan transformasional diakui sebagai faktor utama yang menyebabkan hal tersebut (Atwater and Bass, 1994; Burke and Litwin, 1992; Worley et al., 1996)

Dalam organisasi pemerintah, sebagaimana Badan Pengembangan Sumber Daya Manusia Provinsi (BPSDMP), kepemimpinan transformasional memiliki peran penting dalam meningkatkan hasil-hasil organisasi. Berdasarkan studi pendahuluan yang penulis lakukan melalui wawancara awal secara on line, terhadap 50 pegawai BPSDMP di kota Ambon, Palu, Jakarta, dan Medan, sebagian besar (40\%) menyatakan bahwa mereka kecewa dengan perilaku pemimpinnya di organisasi. Lebih lanjut, perilaku pemimpinnya tersebut menurunkan kepercayaan mereka dan motivasi dalam bekerja. Berdasarkan studi pendahuluan yang dilakukan, dapat dibayangkan sulitnya kondisi tersebut khususnya dalam organisasi pemerintahan. Oleh karena hal tersebut, maka kondisi organisasi memiliki tingkat resiko dan kerentanan dalam hubungan antara atasan dan bawahan, setiap orang dalam organisasi akan selalu berbohong, suka berdalih, atau bahkan melakukan tindakan penipuan demi kepentingan diri sendiri. Secara umum hal tersebut disebabkan karena anggota dalam organisasi tidak berperilaku konsisten terhadap janji dan komitmen untuk selalu setia terhadap pemimpin dan organisasi, yang berdampak pada menurunnya motivasi kerjanya.
Sebagaimana yang dinyatakan oleh Bligh (2017), bahwa kepercayaan adalah sesuatu yang bersifat dinamis, menggambarkan hubungan interpersonal antara sesama anggota organisasi, yang memberikan dampak unik terhadap situasi kerja. Lebih lanjut, Dirks and Ferrin (2002) menyatakan bahwa kepercayaan adalah harapan atau keyakinan ketika seseorang memegang teguh tindakan dan perkataan orang lain dan orang lain tersebut berniat untuk menepati janjinya. Berdasarkan hal ini, maka kepercayaan merupakan faktor yang sangat penting dalam hubungan antara atasan dan bawahan khususnya di organisasi pemerintah seperti BPSDMP. Berdasarkan tinjauan literatur yang penulis lakukan, sebagian besar penelitian di bidang kepemimpinan mengabaikan peran kepercayaan sebagai faktor penting yang memediasi hubungan antara perilaku pemimpin dengan motivasi kerja bawahan.

Dalam penelitian ini, ingin diungkap mengenai pentingnya variabel kepercayaan sebagai dasar dalam proses kognitif dan afektif yang melibatkan hubungan antara kepemimpinan transformasional dengan motivasi. Hal ini karena kepercayaan merupakan konsep hubungan yang selalu muncul di antara orang, dalam organisasi seperti BPSDMP, baik pemimpin maupun bawahan memainkan peran penting dalam menciptakan, mempertahankan, merusak, dan membangun kembali hubungan atas dasar kepercayaan.

\section{RUMUSAN MASALAH}

Selama ini banyak penelitian-penelitian mengenai kepemimpinan transformasional telah memusatkan perhatian pada pengembangan model konseptual serta pengaruhnya terhadap hasil-hasil dalam organisasi, seperti kepuasan, komitmen dan niat untuk berhenti (Yukl, 2013; Northouse, 2016). Penelitian lanjutan dengan situasi dan kondisi yang mampu mengungkap mengenai peran kepercayaan dalam kepemimpinan transformasional, akan memberikan gambaran yang jelas mengenai pengaruh kepemimpinan tersebut untuk membentuk kepercayaan bawahan (Christie et al., 2011). Lebih lanjut, hal tersebut akan menjadi dasar kondisi dalam menciptakan lingkungan kerja yang mampu memotivasi bawahan (Christie et al., 2011).

Bagaimanapun juga berdasarkan tinjauan literatur yang penulis lakukan masih jarang penelitian-penelitian yang menggambarkan mengenai hubungan antara kepemimpinan transformasional, kepercayaan, dan motivasi kerja. Sebagaimana yang dinyatakan oleh Christie et al (2011), perlu diungkap mengenai hubungan 
antar ketiga variabel tersebut. Oleh karena itu penelitiankan ini bertujuan untuk mengungkap mengenai hubungan antara kepemimpinan tranformasional, kepercayaan, dan motivasi kerja, sehingga memberikan informasi yang bernilai kepada organisasi untuk dapat memusatkan perhatian pada pembentukan lingkungan kerja yang mampu memotivasi kerja pegawai demi tercapainya tujuan.

\section{TUJUAN PENELITIAN}

Tujuan utama penelitian ini secara empiris adalah mengungkap hubungan antar konstruk kepemimpinan transformasional, kepercayaan, dan motivasi para pegawai di BPSDMP sehingga memberikan gambaran terhadap organisasi untuk mampu merancang bentuk kepemimpinan yang efektif yang berdampak pada ikatan emosional serta motivasi kerja.

\section{TINJAUAN TEORI DAN PEMBENTUKAN HIPOTESIS}

Bligh (2017) dalam penelitiannya menyatakan bahwa peran kepercayaan dalam kepemimpinan transformasional telah lama disadari oleh para peneliti-peneliti lainnya. Model kepemimpinan transformasional sebagaimana yang dinyatakan oleh Bass, berpendapat bahwa gaya kepemimpinan ini sangat efektif dalam membentuk kepercayaan pengikut. Beberapa penelitian seperti yang dilakukan oleh Dirks dan Ferrin (2002) serta Colquitt et al (2007) menyatakan bahwa hubungan antara kepemimpinan transformasional dan kinerja bergantung pada kepercayaan antara pemimpin dan bawahan serta nilainilai yang bersesuaian. Sebagai contoh, dalam sebuah kelompok penelitian dan pengembangan, ketika pemimpin berkonsultasi dengan semua anggota kelompok untuk membuat keputusan, mengkomunikasikan visi organisasi, dan berbagi nilai-nilai bersama dengan pemimpinnya, maka $67 \%$ karyawan percaya terhadap pemimpinnya (Bligh, 2017).

Secara bersama-sama, perilaku kepemimpinan seperti ini menunjukkan bahwa pemimpin tidak mungkin menghancurkan kepercayaan pengikutnya, memungkinkan pengikut untuk berbagi informasi yang sensitif dan bergantung pada penilaian pemimpin dalam situasi yang ambigu. Selain itu, kepercayaan telah menjadi konsep kunci dalam beberapa teori kepemimpinan. Ketika pemimpin menerapkan gaya kepemimpinan karismatik dan transformasional, maka hal itu akan membangun kepercayaan pengikut (Kirkpatrick dan Locke, 1991; Podsakoff et al.,
1990). Dengan demikian, kombinasi teori dan bukti empiris yang tersedia menunjukkan bahwa harus ada hubungan positif antara kepemimpinan transformasional dan kepercayaan.

\section{H1: kepemimpinan transformasional berpengaruh positip pada kepercayaan para pegawai di BPSDMP}

Menurut Dirks dan Ferrin (2002), kepercayaan pada pemimpin secara signifikan berhubungan dengan berbagai hasil sikap, perilaku, dan kinerja. Untuk perilaku dan hasil kerja, kepercayaan berhubungan dengan semua bentuk perilaku kewarganegaraan organisasional (OCB), seperti altruisme, kebajikan sipil, kesadaran, kesopanan, dan sportivitas (Bligh, 2017). Kepercayaan pada perilaku kepemimpinan juga secara signifikan mempengaruhi kepuasan kerja karyawan dan komitmen organisasi serta secara positif berhubungan dengan motivasi kerja karyawan di organisasi (Yukl, 2013; Northouse, 2016).

Kepercayaan memiliki hubungan yang signifikan dengan motivasi kerja dan komitmen organisasi (Bass dan Riggio, 2006). Pada akhirnya, dan tidak mengherankan, kepercayaan juga sangat berhubungan dengan motivasi seseorang terhadap pemimpin dan persepsi terhadap kualitas hubungan antara pemimpin dan pengikut (De Cremer dan van Knippenberg, 2005). Selain itu, mereka berpendapat bahwa kepercayaan pengikut pada pemimpin secara kolektif memiliki peran penting karena menggambarkan pengorbanan seorang pemimpin yang mampu memotivasi para pengikut. Menurut Chiaburu dan Marinova (2006), kepercayaan pengikut terhadap pemimpin mampu meningkatkan motivasi dan perilaku kewargaan organisasi. Motivasi kerja dalam penelitian ini menggunakan konsep motivasi kerja di sektor pelayanan publik atau pemerintahan (sesuai dengan latar penelitian ini yaitu BPSDMP) yang dikemukakan oleh Perry (1996), yaitu motivasi kerja yang didasarkan pada hasrat untuk berbuat baik bagi orang/masyarakat secara umum yang menerima pelayanan dari pemerintah.

Dengan demikian, berdasarkan teori dan bukti empiris menunjukkan bahwa harus ada hubungan positif antara kepercayaan pengikut dan motivasi kerja.

\section{H2: Kepercayaan terhadap pemimpin berpengaruh positip pada motivasi pegawai BPSDMP}

Dengan demikian, model teoritis yang diajukan dalam penelitian ini adalah: 


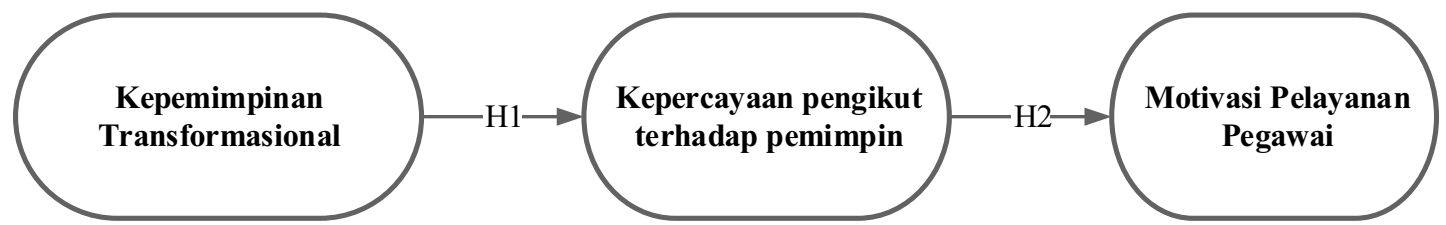

Gambar 1. Model teoritis

\section{METODE PENELITIAN}

Dalam penelitin ini dilakukan wawancara pendahuluan. Wawancara dilakukan terhadap 100 responden sebagai informan kunci untuk mengungkap fenomena kepemimpinan transformasional di tempat kerja. Selanjutnya mengungkap mengenai hubungan antara kepemimpinan transformasional dengan kepercayaan dan motivasi kerja pekerja PNS. Setelah itu, dibentuk kuesioner yang akan digunakan sebagai alat pengukuran penelitian berdasarkan wawancara pendahuluan dengan 100 informan kunci. Indikator-indikator dalam pengukuran ini diuji validitas (diskriminan dan konvergensi) dan reliabilitasnya, serta dilakukan uji tanggapan keinginan sosial,. Setelah hasil validitas yang memadai telah diperoleh, selanjutnya dilakukan pengukuran dampak kepemimpinan transformasional pada motivasi kerja yang dimediasi oleh kepercayaan pengikut.

\section{Populasi dan Besaran Sampel}

Populasi dalam penelitian ini adalah para pegawai yang bekerja di kantor BPSDMP di kota Ambon, Palu, Jakarta, dan Medan. Teknik penarikan sampel menggunakan penyampelan purposif. Kategori responden yang digunakan dalam penelitian ini adalah: (1) laki-laki dan perempuan, (2) bekerja di kantor BPSDMP yang berada di kota Ambon, Palu, Jakarta, dan Medan, (3) bersedia untuk terlibat dalam penelitian. Hair et al (2010) menyatakan bahwa besaran sampel minimum yang dibutuhkan ketika menganalisis dengan model persamaan struktural (Structural Equation Modelling/SEM) adalah lima sampai dengan sepuluh dikalikan dengan jumlah indikator.

Dalam penelitian ini jumlah indikator pengukuran adalah 22. Oleh karena itu, berdasarkan pernyataan Hair et al (2010), maka besaran sampel minimum dalam penelitian ini adalah $22 \times 10=$ 220 responden. Berdasarkan pernyataan Aaker et al (2007) semakin besar sampel yang digunakan maka hasil penelitian akan semakin baik, hal ini karena sampel yang besar akan mengurangi tingkat kesalahan penyampelan (error sampling).
Dengan demikian, besaran sampel yang ditetapkan dalam penelitian ini adalah 300 responden.

\section{Definisi operasional dan pengukuran}

Menurut Yukl (2013) dan Northouse (2016) bahwa kepemimpinan transformasional adalah kepemimpinan yang memiliki dampak besar secara pribadi pada nilai-nilai pengikut, aspirasi, cara berpikir tentang pekerjaan, dan menafsirkan suatu kejadian atau peristiwa. Bass dan Riggio (2006) mengidentifikasi empat faktor kepemimpinan atau perilaku yang menjadi ciri kepemimpinan transformasional. Yang pertama adalah pengaruh yang diidealkan (idealized influence). Faktor ini mendefinisikan bahwa perilaku pemimpin akan menumbuhkan kekaguman, rasa hormat, dan kepercayaan pada dirinya sendiri dari para pengikut. Perilaku kepemimpinan transformasional yang kedua menurut Bass adalah motivasi yang menginspirasi (inspirational motivation), yang mengacu pada tindakan yang dilakukan pemimpin untuk menyajikan visi, menetapkan standar yang tinggi, dan meyakinkan individu bahwa mereka dapat mencapai hasil di luar harapan. Perilaku kepemimpinan transformasional ketiga adalah stimulasi intelektual (intellectual stimulation), yang mencakup tindakan yang dilakukan para pemimpin untuk mempromosikan pengembangan intelektual pengikut, menantang bawahan untuk berpikir demi diri mereka sendiri dan untuk mengevaluasi masalah dengan cara-cara yang inovatif. Perilaku kepemimpinan transformasional keempat adalah pertimbangan individual (individualized consideration), yang berfokus pada hubungan antara pemimpin dan setiap pengikut.

Menurut Dirks dan Ferrin (2002), sebagian besar penelitian mengidentifikasi dua fondasi inti dalam hubungan kepercayaan antara pemimpin dan pengikut. Yang pertama adalah kompetensi atau kemampuan, yang melibatkan persepsi bahwa pihak lain memiliki pengetahuan dan keterampilan yang dibutuhkan untuk melakukan suatu pekerjaan, bersama dengan keterampilan interpersonal dan kebijaksanaan umum yang diperlukan untuk 
berhasil. Landasan kedua adalah karakter, yang kemudian dibagi menjadi dua konstruksi yang berbeda: kebajikan, atau sejauh mana orang yang dipercaya diyakini ingin berbuat baik untuk yang mempercayainya, dan integritas, atau sejauh mana orang yang dipercaya diyakini mengikuti suara sesuai dengan prinsip etika.

Menurut Perry dan Wise (1990) serta Perry (1996), motivasi yang didorong terutama oleh keinginan untuk mendapatkan manfaat bagi diri sendiri sangat berbeda dengan motivasi yang didorong oleh keinginan untuk berbuat baik bagi orang lain. Motivasi yang didorong karena adanya keinginan untuk berbuat baik demi orang lain didefinisikan sebagai motivasi prososial. Dengan kata lain, motivasi prososial sesuai dengan konsep motivasi dalam pelayanan publik atau pemerintahan. Perry dan Wise (1990) berpendapat bahwa motivasi pelayanan publik merupakan jenis motivasi prososial yang tidak hanya berlaku dalam konteks pemberian layanan publik tetapi juga dapat membantu untuk memprediksi perilaku dan kinerja orang yang terlibat dalam menyediakan layanan publik.

Dalam penelitian ini, konstruk kepemimpinan transformasional diukur dengan menggunakan indikator-indikator yang dikembangkan oleh Bass and Avolio (1990; 1995). Konstruk kepercayaan pegawai BPSDMP diukur dengan menggunakan indikator-indiktator yang dikembangkan oleh Dirks and Ferrin (2002) and Zacharatos et al (2005). Konstruk motivasi kerja para pegawai BPSDMP diukur dengan menggunakan indikator-indikator yang dikembangkan oleh Perry (1996) mengenai motivasi kerja para pegawai pemerintahan yang memberikan pelayanan kepada masyarakat. Skala pengukuran konstruk dalam penelitian ini menggunakan skala Likert, 1 to 5, $1=$ Sangat Tidak Setuju; $2=$ Tidak Setuju; $3=$ Netral; $4=$ Setuju; $5=$ Sangat Setuju.

\section{Teknik Analisis Data}

Teknik analisis data dalam penelitian ini menggunakan Structural Equation Modeling (SEM) atau pemodelan persamaan struktural dengan bantuan program Warp PLS 6 and SPSS. Metode analisis data menggunakan SEM dengan pendekatan dua tahap, yaitu: model pengukuran dan model struktural sebagaimana yang dinyatakan oleh Anderson and Gerbing (1988) (lihat: Gefen et al (2011)). Evaluasi model pengujian menggunakan beberapa kriteria sesuai dengan Goodness of Fit (GOF) yang dikemukakan oleh Amato et al (2004) (lihat: Tenenhaus et al (2005)) untuk model SEM berbasis varians.

\section{HASIL DAN PEMBAHASAN}

Tabel 1. Karakteristik Responden

\begin{tabular}{|lcc|}
\hline Profil & Jumlah & Persentase \\
\hline Jenis kelamin & & \\
Laki-laki & 120 & 40 \\
Perempuan & 180 & 60 \\
Status Pernikahan & & \\
Menikah & 160 & 53.3 \\
Belum menikah & 140 & 46.7 \\
Usia & & \\
$<30$ tahun & 70 & 23.3 \\
31-45 & 200 & 66.7 \\
$>45$ tahun & 30 & 10 \\
Golongan & & \\
III B & 40 & 13.3 \\
III C & 60 & 20 \\
III D & 120 & 40 \\
IV A & 50 & 16.7 \\
IV B & 30 & 10 \\
Pendidikan & & \\
Sarjana & 140 & 46.7 \\
Magister & 160 & 53.3 \\
Masa kerja (tahun) & & \\
5-10 & 13 & 4.3 \\
11-15 & 112 & 37.3 \\
16-20 & 100 & 33.3 \\
$>$ 20 & 75 & 25 \\
\hline
\end{tabular}

Berdasarkan data di Tabel 1 menunjukkan bahwa responden dalam dalam penelitian ini didominasi oleh jenis kelamin perempuan, dengan status menikah, usia antara 31 sampai dengan 45 tahun, golongan $3 \mathrm{D}$, tingkat pendidikan adalah magister, dengan masa kerja antara 11 sampai dengan 15 tahun.

\section{Pengujian model pengukuran (validitas konstruk)}

Berdasarkan Tabel 2, mengenai hasil pengujian model pengukuran (validitas diskriminan dan validitas konvergensi) menunjukkan bahwa konstruksi motivasi pelayanan memiliki validitas yang baik dengan nilai AVE (Average Variance Extracted) yang melebihi 0,5 (Hair et al., 2010, 2011, 2012). Untuk nilai AVE pada konstruk kepemimpinan transformasional dan kepercayaan yang memiliki indikator formatif tidak memiliki nilai. Selain itu, Tabel 2 menunjukkan bahwa nilai Cronbach Alpha dan nilai reliabilitas komposit untuk konstruk dengan indikator reflektif (motivasi pelayanan) melebihi 0,7 , sehingga dapat dinyatakan bahwa konstruk reflektif dalam 
penelitian dapat dinyatakan reliabel (Hair et al., 2010, 2011, 2012).

Dalam penelitian ini, pengujian internal konsistensi menggunakan reliabilitas komposit karena keunggulannya dalam mengestimasi nilai konsistensi internal suatu konstruk serta mampu memastikan bahwa konstruk tersebut benar-benar unidimensional (Hair et al., 2010, 2011, 2012).

Untuk konstruk dengan indikator formatif, Tabel 2 menunjukkan bahwa nilai weight indicator untuk dua konstruk formatif dalam penelitian ini (kepemimpinan transformasional dan kepercayaan) adalah signifikan pada nilai $p<0,001$ dan $p$ $<0,05$. Lebih lanjut, nilai VIF untuk kedua konstruk tersebut di bawah nilai 3,3 sebagaimana yang disyaratkan untuk konstruk dengan indikator formatif (Kock, 2013). Dengan demikian, semua indikator formatif untuk konstruk kepemimpinan transformasional dan kepercayaan dinyatakan layak untuk digunakan pada tahap pengujian model struktural.

Table 2. Hasil Uji Model Pengukuran

\begin{tabular}{|c|c|c|c|c|c|c|}
\hline $\begin{array}{l}\text { Konstruk (Cronbach } \\
\text { Alpha) }\end{array}$ & Indikator & $\begin{array}{l}\text { Faktor } \\
\text { loading }\end{array}$ & $\begin{array}{c}\text { Reliabilitas } \\
\text { komposit }\end{array}$ & $\begin{array}{c}\text { AVE (Average } \\
\text { Variance Extracted) }\end{array}$ & Nilai $\mathrm{p}$ & VIF \\
\hline \multirow{5}{*}{$\begin{array}{l}\text { Kepemimpinan } \\
\text { Transformasional }\end{array}$} & TLB1 & 0,636 & & & $<0,001$ & 1,255 \\
\hline & TLB2 & 0,673 & & & $<0,001$ & 1,332 \\
\hline & TLB3 & 0,841 & & & $<0,001$ & 1,908 \\
\hline & TLB4 & 0,814 & & & $<0,001$ & 2,035 \\
\hline & TLB5 & 0,755 & & & $<0,001$ & 1,459 \\
\hline \multirow{7}{*}{ Kepercayaan } & TR1 & 0,755 & & & $<0,001$ & 1,540 \\
\hline & TR2 & 0,748 & & & $<0,001$ & 1,970 \\
\hline & TR3 & 0,827 & & & $<0,001$ & 2,145 \\
\hline & TR4 & 0,642 & & & $<0,001$ & 1,357 \\
\hline & TR5 & 0,661 & & & $<0,001$ & 1,349 \\
\hline & TR6 & 0,826 & & & $<0,001$ & 1,394 \\
\hline & TR7 & 0,805 & & & $<0,001$ & 1,327 \\
\hline \multirow{10}{*}{ Motivasi Pelayanan } & PSM1 & 0,624 & \multirow{10}{*}{0,795} & \multirow{10}{*}{0,594} & & \\
\hline & PSM2 & 0,788 & & & & \\
\hline & PSM3 & 0,775 & & & & \\
\hline & PSM4 & 0,791 & & & & \\
\hline & PSM5 & 0,817 & & & & \\
\hline & PSM6 & 0,601 & & & & \\
\hline & PSM7 & 0,694 & & & & \\
\hline & PSM8 & 0,798 & & & & \\
\hline & PSM9 & 0,705 & & & & \\
\hline & PSM10 & 0,900 & & & & \\
\hline
\end{tabular}

Tabel 3 menunjukkan hasil pengujian diskriminan untuk semua konstruk yang akan diukur dalam penelitian ini. Hasil pengujian ditunjukkan dengan membandingkan nilai akar AVE yang terletak secara diagonal (huruf tebal) dengan nilai korelasi antar konstruk. Jika nilai akar AVE tersebut lebih besar dibandingkan dengan nilai korelasi antar konstruk, maka konstrukkonstruk yang digunakan dalam penelitian ini memiliki validitas diskriminan yang baik (Hair et al., 2010, 2011, 2012). Berdasarkan Tabel 3, nilai akar AVE lebih besar dibandingkan dengan nilai korelasi antar konstruk, sehingga dapat disimpulkan bahwa konstruk-konstruk dalam penelitian ini memiliki validitas diskrimianan yang baik.
Table 3. Nilai akar AVE dan korelasi antar konstruk

\begin{tabular}{llccc}
\hline & Konstruk & 1 & 2 & 3 \\
\hline 1 & Kepemimpinan & $\mathbf{0 , 7 5 9}$ & 0,452 & 0,424 \\
& Transformasional & & & \\
2 & Kepercayaan & 0,452 & $\mathbf{0 , 7 2 5}$ & 0,546 \\
3 & Motivasi pelayanan & 0,424 & 0,546 & $\mathbf{0 , 7 3 8}$ \\
\hline
\end{tabular}

\section{Pengujian Model Struktural}

Pengujian model pengukuran dalam penelitian ini menggunakan Structural Equation Modeling (SEM) untuk mengungkap mengenai validitas model penelitian sesuai dengan hipotesis yang diajukan dalam mengukur pengaruh antar konstruk. Pengujian ini dilakukan dengan bantuan 
program WarpPLS 6.0. Hasil pengujian dapat dilihat pada Tabel 4.

Tabel 4. Hasil Estimasi Parameter Struktural

\begin{tabular}{|l|l|l|l|}
\hline Hipotesis & Koefisien & Nilai t & Kesimpulan \\
\hline H1 & 0,18 & 5.52 & Terdukung \\
\hline H2 & 0,11 & 4.16 & Terdukung \\
\hline
\end{tabular}

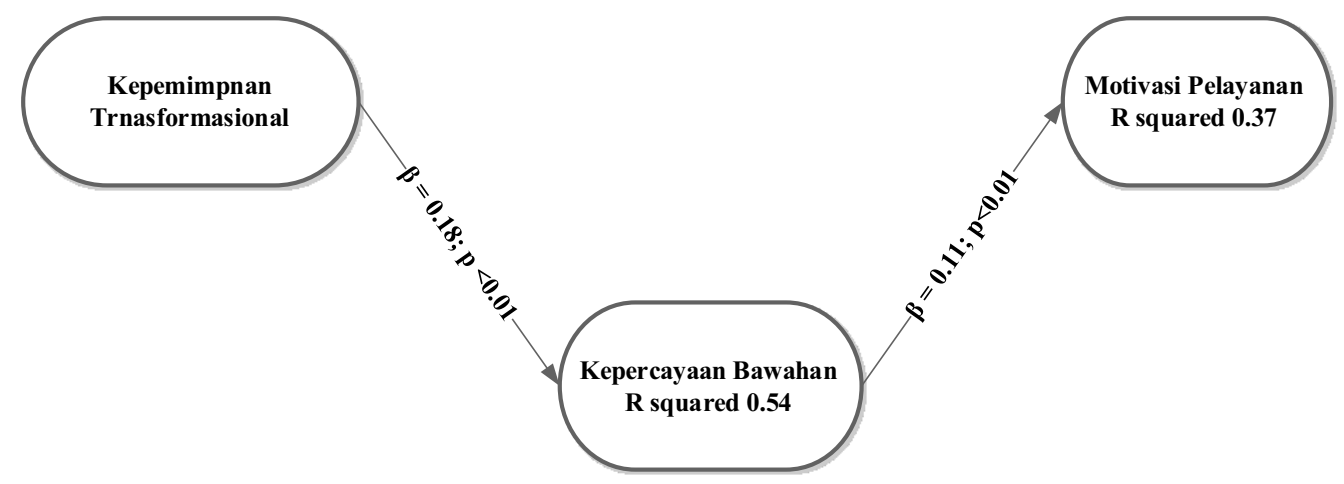

Gambar 2. Estimasi Parameter Model Persamaan Struktural

Berdasarkan Gambar 2 dan Tabel 4, kepemimpinan transformasional memiliki pengaruh positip dan signifikan terhadap kepercayaan bawahan/pegawai, juga pengaruh kepercayaan tersebut terhadap motivasi pelayanan para bawahan/pegawai. Tabel 4 menunjukkan bahwa nilai $\mathrm{t}>1,96$ dan signifikan pada $\mathrm{p}<0,01$ untuk masing-masing parameter. Lebih lanjut, Gambar 2 dan Tabel 4 menunjukkan bahwa kepemimpinan transformasional mampu menjelaskan 54\% varians dari kepercayaan bawahan/pegawai, dan kercayaan mampu menjelaskan $37 \%$ varians dari motivsi pelayanan pegawai.

Secara umum, model penelitian ini memiliki nilai Goodness of Fit (GoF) yang baik. Lihat Tabel 5 yang merupakan output dari program Warp PLS 6 mengenai indeks GoF penelitian ini.

Tabel 5. Model fit dan quality indices

\begin{tabular}{|l|}
\hline Average path coefficient $(\mathrm{APC})=0.295, \mathrm{P}<0.001$ \\
\hline Average R-squared (ARS) $=0.419, \mathrm{P}<0.001$ \\
\hline Average adjusted R-squared (AARS) $=0.417, \mathrm{P}<0.001$ \\
\hline Average block VIF (AVIF) $=2.048$, acceptable if $<=5$, ideally $<=3.3$ \\
\hline Average full collinearity VIF (AFVIF) $=2.565$, acceptable if $<=5$, ideally $<=3.3$ \\
\hline Tenenhaus GoF $($ GoF) $=0.495$, small $>=0.1$, medium $>=0.25$, large $>=0.36$ \\
\hline Sympson's paradox ratio (SPR $)=1.000$, acceptable if $>=0.7$, ideally $=1$ \\
\hline R-squared contribution ratio $(\mathrm{RSCR})=1.000$, acceptable if $>=0.9$, ideally $=1$ \\
\hline Statistical suppression ratio $(\mathrm{SSR})=1.000$, acceptable if $>=0.7$ \\
\hline Nonlinear bivariate causality direction ratio $(\mathrm{NLBCDR})=0.857$, acceptable if $>=0.7$ \\
\hline
\end{tabular}


Berdasarkan output pada Tabel 5, model penelitian ini sesuai dengan data. Variabel laten yang digunakan dalam model penelitian ini tidak memiliki masalah multikolinearitas. Lebih lanjut, hubungan antara variabel laten seperti yang dinyatakan dalam hipotesis penelitian bebas dari paradoks Simpson dan kontribusi negatif Rsquared yang biasanya terjadi bersama dengan paradoks Simpson. Tabel 5 juga menunjukkan bahwa model penelitian ini tidak mengalami masalah kausalitas. Dengan kata lain, hubungan antara variabel yang dihipotesiskan dengan nilai koefisien yang dihasilkan dapat diterima. Dengan demikian, secara keseluruhan, model penelitian ini memiliki GoF yang sesuai.

Hasil estimasi parameter struktural yang menggunakan SEM berbasis varians, dengan bantuan Warp PLS 6, mendukung Hipotesis 1 (H1) yang menyatakan bahwa kepemimpinan transformasional memiliki pengaruh positif pada kepercayaan bawahan/pegawai di BPSDMP terdukung. Hasil ini sesuai dengan penelitian yang dilakukan oleh Podsakoff et al (1990). Mereka berpendapat bahwa pemimpin yang transformasional akan membangun kepercayaan pada pengikut mereka. Sejalan dengan mereka, Hogan et al (1994) juga menyarankan bahwa persepsi pengikut terhadap atribut pemimpin yang mempromosikan kepercayaan sangat penting untuk efektivitas kepemimpinan. Selain itu Schriesheim et al (1999) juga menyatakan bahwa kepercayaan adalah elemen dari teori pertukaran mengenai pemimpinbawahan dan dimensi yang dipertimbangkan dalam perilaku seorang pemimpin. Kepemimpinan transformasional pada dasarnya didasarkan pada kepercayaan, yang mendorong proses dengan lebih jujur dan langsung ketika menghadapi masalah yang sulit. Seorang pemimpin yang memiliki kredibilitas pertama-tama harus memberikan perhatian terhadap pengikut potensialnya sebelum mereka setuju untuk dipimpin ke arah yang baru. Dengan demikian, pemimpin yang lebih transparan dan positif lebih cenderung memiliki pengikut yang mempercayainya dan menilai dia sebagai pemimpin yang efektif.

Selanjutnya, Hipotesis 2 yang menyatakan bahwa kepercayaan bawahan/pegawai terhadap pemimpin BPSDMP di Indonesia memiliki pengaruh positif terhadap motivasi pelayanan terdukung. Sejalan dengan penelitian yang dilakukan oleh Brown et al (2015), mereka berpendapat bahwa kepercayaan pengikut kepada pemimpin akan memotivasi mereka untuk mennghasilkan kinerja. Sebelumnya, Brown et al (2011) menyatakan bahwa perilaku karyawan dapat mempengaruhi tingkat kinerja organisasi mengingat bahwa banyak karyawan yang diberikan keleluasaan sehubungan dengan upayakerja kerasnya, sehingga membentuk hubungan antara komitmen dan kinerjanya di tempat kerja. Hal inilah yang memungkinkan bahwa kepercayaan karyawan di tempat kerja mempengaruhi perilaku karyawan, yang pada gilirannya mempengaruhi motivasi kerjanya (Dirks dan Ferrin, 2002). Secara khusus, sejauh mana karyawan percaya bahwa pemimpin mereka akan memperlakukan mereka dengan jujur dan adil dapat mempengaruhi sejauh mana karyawan terlibat dalam perilaku oportunistik atau sebaliknya. Dengan demikian, tingkat kepercayaan yang dimiliki karyawan terhadap pemimpin mereka dapat berdampak pada kinerja organisasi

\section{KESIMPULAN}

Peran kepemimpinan transformasional dalam organisasi pemerintah seperti BPSDMP sangat penting. Hal ini karena kepemimpinan transformasional adalah jenis kepemimpinan yang mampu memotivasi bawahan/pegawai dalam meningkatkan kinerja mereka. Dengan demikian, tujuan organisasi dapat tercapai. Jelas, hal ini tidak terlepas dari pembentukan kepercayaan bawahan/ pegawai terhadap para pemimpin yang pada gilirannya mereka termotivasi untuk bekerja lebih baik. Sebagaimana yang dijelaskan oleh Dirks dan Ferrin (2002) mengenai karakter pemimpin, bahwa secara individu, bawahan/pegawai cenderung merasa lebih aman dan bersikap lebih positif terhadap pemimpinnya yang membuat keputusan ketika mereka percaya bahwa pemimpin tersebut dapat dipercaya.

Situasi dan kondisi BPSDMP di Indonesia sejalan dengan penelitian yang dilakukan oleh Mayer et al (1995). Mereka mengusulkan suatu model bahwa ketika pengikut percaya terhadap pemimpinnya yang memiliki integritas, kemampuan atau kebajikan, mereka akan lebih nyaman terlibat dalam perilaku meski itu berisiko (mis., Berbagi informasi sensitif). Selain itu, Mayer dan Gavin (1999) menyarankan bahwa ketika bawahan/pegawai percaya bahwa pemimpinnya tidak dapat dipercaya (misalnya, karena pemimpin dianggap tidak memiliki integritas), mereka akan beralih yang berdampak pada penurunan kinerja mereka.

Hal ini selalu terjadi di organisasi pemerintah seperti BPSDMP. Peran pemimpin sangat penting dalam membentuk kepercayaan bawahan/pengikutnya. Ketika kepercayaan pengikut telah terbentuk dengan benar, maka para pemimpin 
organisasi akan dapat membentuk motivasi mereka dalam memberikan pelayanan. Dengan demikian, pengikut akan memberikan layanan kepada masyarakat dengan upaya maksimal. Sebagaimana yang dinyatakan oleh Frazier et al (2010) bahwa kepercayaan pada pemimpin langsung mengarah pada peningkatan motivasi untuk fokus pada tugas dan pekerjaan. Dalam hal ini, kepercayaan bawahan terhadap pemimpin di organisasi BPSDMP memungkinkan mereka untuk fokus dan memberikan nilai tambah bagi organisasi melalui motivasi untuk menghasilkan kinerja yang baik.

\section{IMPLIKASI MANAJERIAL}

Hasil penelitian ini memberikan masukan bagi organisasi BPSDMP di Indonesia agar memperhatikan faktor-faktor yang membentuk perilaku pemimpin karena kemampuan mereka dalam mempengaruhi kepercayaan yang akan berdampak pada motivasi bawahan/pegawai. Selanjutnya, dengan adanya kepercayaan dan motivasi bawahan/pegawai dalam memberikan pelayanan, maka reputasi lembaga yang menyelenggarakan program pendidikan dan pelatihan akan meningkat. Kepemimpinan transformasional secara strategis sangat penting karena kemampuannya dalam membangun kepercayaan dan motivasi pegawai organisasi yang akan mempengaruhi pencapaian proses kinerja dalam pekerjaan mereka. Dengan demikian, BPSDMP di Indonesia akan menumbuhkan citra pemimpin yang unggul di mata organisasi pemerintah daerah lainnya yang mampu memuaskan pegawai sehingga terbangun kepercayaan dan motivasi dalam memberikan pelayanan. Kepercayaan juga memainkan peran penting ketika pemimpin mengatakan tidak. Dalam satu penelitian, pengikut yang merasa pemimpinnya transformasional menunjukkan tingkat kepercayaan yang lebih tinggi dan reaksi yang lebih baik terhadap penjelasan manajerial meskipun ketika jawabannya bukan jawaban yang ingin didengar oleh bawahan/pegawai (Bligh, 2017). Penelitian ini memberikan bukti bahwa menginvestasikan waktu dan energi dalam mengembangkan gaya kepemimpinan transformasional seseorang dan hubungan saling percaya antar pemimpin bawahan merupakan suatu keuntungan besar meski organisasi berada dalam situasi dan kondisi yang sulit.

\section{Daftar Pustaka}

Aaker, D. A, V. Kumar, G. S. Day, and R. Leone (2007), Marketing Research, $10^{\text {th }}$ ed. New York: Jhon Wiley and Sons, Ltd.
Atwater, D., and B. Bas s (1994), "Transformational leadership in teams, "In $B$. Bass, \& B. Avolio (Eds.), Improving organizational effectiveness through transformational leadership (pp. 48 - 83). Thousand Oaks, CA: Sage Publications

Bass, B. M. (1985), "Comment: Transformational leadership. Looking at other possible antecedents and consequences, "Journal of Management Inquiry, Vol. 4, pp. 293-297.

Bass, B. M. (1995), "Transformational leadership: Looking at other possible antecedents and consequences, "Journal of Management Inquiry, Vol. 4, pp. 293-297.

Bass, B. M. (1997), "Does the transactional -transformational leadership paradigm transcend organizational and national boundaries? "American Psychologist, Vol. 52, pp. $130-139$.

Bass, B. M., and B. J. Avolio (1990). Multifactor Leadership Questionnaire. Palo Alto, CA: Consulting Psychologists Press.

Bass, B. M., and B. J. Avolio (1995). Multifactor Leadership Questionnaire for research. Menlo Park, CA: Mind Garden.

Bass, B. M. and R. E. Riggio. (2006). Transformational Leadership. $2^{\text {nd }}$ edition. Mahwah, New Jersey, London: Lawrence Erlbaum Associates, Inc.

Bligh, M. C. (2017). Leadership and Trust. In J. Marques, S. Dhiman (eds.), Leadership Today: Practices for Personal and Professional Performance, Switzerland: Springer International Publishing, pp. 21-42

Brown, S., J. Mchardy, R. McNabb, and K. Taylor (2011), "Workplace performance, worker commitment and loyalty, "Journal of Economics and Management Strategy, Vol. 20, pp. 925-955

Brown, S., D. Gray, J. McHardy, and K. Taylor (2015), "Employee trust and workplace performance, "Journal of Economic Behavior \& Organization Vol. 116, pp. 361-378

Burke, W. W., and G. H. Litwin (1992), “A causal model of organizational performance and change, "Journal of Management, Vol. 18, pp. $523-545$

Bycio, P., R. Hackett, and J. Allen (1995), "Further assessment of Bass's (1985) conceptualization of transactional and transformational leadership, "Journal of Applied Psychology, Vol. 80, pp. $468-478$

Cascio, W. F. (1993), "Downsizing: What do we know? What have we learned? "Academy of Management Executive, Vol. 7, pp. 95-104 
Chiaburu, D. S. and S. V. Marinova (2006), "Employee role enlargement: Interactions of trust and organizational fairness, "Leadership and Organization Development Journal, Vol. 27, No. 3, pp. 168-182.

Christie, A., J. Barling, and N. Turner (2011), "Pseudo-transformational leadership:

Model specification and outcomes, "Journal of Applied Social Psychology, Vol. 44, No. 12, pp. 2943-2984.

Colquitt, J. A., B. A. Scott, and J. A. LePine. (2007), "Trust, Trustworthiness, and Trust Propensity: A Meta-Analytic Test of Their Unique Relationships With Risk Taking and Job Performance, "Journal of Applied Psychology, Vol. 92, No. 4, pp. 909-927

De Cremer, D., and D. van Knippenberg (2005), "Cooperation as a function of leader selfsacrifice, trust, and identification, "Leadership and Organization Development Journal, Vol. 26, No. 5, pp. 355-369.

Dirks, K. T. and D. L. Ferrin. (2002), "Trust in Leadership: Meta-Analytic Findings and Implications for Research and Practice, "Journal of Applied Psychology, Vol. 87, No. 4, pp. 611-628

Frazier, M., P. D. Johnson, M. Gavin, J. Gooty, and D. D. Bradley Snow (2010), "Organizational justice, trustworthiness, and trust: A multifoci examination, "Group and Organization Management, Vol. 35, No. 1, pp. 39-76.

Gefen, D., E. E. Rigdon, and D. Straub (2011), “An Update and Extension to SEM Guidelines for Administrative and Social Science Research, “MIS Quarterly, Vol. 35, No. 2, pp. A1-A7

Hair, J. F. Black, W. C., Babin, B. J. and Anderson, R. E. (2010) Multivariate Data Analysis, (7th ed.). Upper Saddle River, NJ: Pearson Education, Ltd.

Hair, J. F., C. M. Ringle, and M. Sarstedt (2011), "PLS-SEM: Indeed a Silver Bullet, "The Journal of Marketing Theory and Practice, Vol. 19, No. 2, pp. 139-152.

Hair, J. F., M. Sarstedt, T. M. Pieper, and C. M. Ringle (2012), "The use of partial least squares structural equation modeling in strategic management research: A review of past practices and recommendations for future applications, "Long Range Planning, Vol. 45, No. 5-6, pp. 320-340.

Hogan, R., G. Curphy, and J. Hogan (1994), "What we know about leadership: Effectiveness and personality, "American Psychologist, Vol. 49, pp. 493-504

Howe11, J., and B. Avolio (1993),
"Transformational leadership, transactional leadership, locus of control, and support for innovation: Key predictors of consolidatedbusiness-unit performance, "Journal of Applied Psychology, Vol. 78, pp. 891-902

Katzenbach, J. R., F. Beckett, S. Dichter, M. Feigen, C. Gagnon, Q. Hope, and T. Ling (1995), Real change leaders: How you can create growth and high performance at your company. New York: Random House

Kirkpatrick, S. A., and E. A. Locke (1996), "Direct and indirect effects of three core charismatic leadership components on performance and attitudes, "Journal of Applied Psychology, Vol. 81, pp. 36-51.

Kock, N. (2013), "Using WarpPLS in ECollaboration Studies: What If I Have Only One Group and One Condition, "International Journal of E-Collaboration, Vol. 9, No. 3, pp. 1-12.

Mayer, R. C., J. H. Davis, and F. D. Schoorman (1995), "An integrative model of organizational trust, "Academy of Management Review, Vol. 20, pp. 709-734

Mayer, R., and M. Gavin (1999), "Trust for management and performance: Who minds the shop while the employees watch the boss? "Paper presented at the Annual Meeting of the Academy of Management, Chicago.

Northouse, P. G. (2016). Leadership: Theory and Practice. 7th. United Stated of America: Sage, Publication, Inc

Perry, J.(1996), "Measuring public service motivation: An assessment of construct reliability and validity, "Journal of Public Administration Research and Theory, Vol. 6, No. 1, pp. 5-22.

Perry, J., and L. Wise (1990), “The motivational bases of public service, "Public Administration Review, Vol. 50, No. 3, pp. 367-373.

Podsakoff, P. M., S. B. MacKenzie, R. H. Moorman, and R. Fetter (1990), "Transformational leader behaviors and their effects on followers' trust in leader, satisfaction, and organizational citizenship behaviors, "The Leadership Quarterly, Vol. 1, pp. 107-142

Podsakoff, P. M., S. B. MacKenzie, J. B. Paine, and D. G. Bachrach (2000), "Organizational citizenship behaviors: A critical review of the theoretical and empirical literature and suggestions for future research, "Journal of Management, Vol.26, pp. 513-563.

Schriesheim, C., S. Castro, and C. Cogliser (1999), "Leader-member exchange (LMX) research: A comprehensive review of theory, measurement, 
and data-analytic procedures, "Leadership Quarterly, Vol. 10, pp. 63-113

Seltzer, J., and B. M. Bass (1990), "Transformational leadership: Beyond initiation and consideration, "Journal of Management, Vol. 16, pp. 693-703.

Tenenhaus, M., V. E. Vinzia, Y. Chatelinc, and C. Lauro (2005), "PLS path modeling, "Computational Statistics and Data Analysis, Vol. 48, No. 1, pp. 159-205

Worley, C. G., D. E. Hitchin, and W. R. Ross. (1996). Integrated strategic change. Reading, MA: Addison-Wesley
Yammarino, F. J., W. D. Spangler, and B. M. Bass (1993), "Transformational leadership and performance: A longitudinal investigation, "The Leadership Quarterly, Vol. 4, pp. 81-102

Yukl, G. 2013. Leadership in Organization. $8^{\text {th }}$ edition. Upper Saddle River, New Jersey: Pearson Education, Inc.

Zacharatos, A., J. Barling, and R. D. Iverson. (2005), "High-Performance Work Systems and Occupational Safety, "Journal of Applied Psychology, Vol. 90, No. 1, pp. 77-93 